\title{
8. May the Less Threatening Leader of the Opposition Win: The cartoonists' view of election 2010
}

\author{
Haydon Manning and Robert Phiddian
}

National affairs correspondent for The Age, Tony Wright, expressed widespread frustration at the media-managed frivolity of the 2010 federal election campaign when he asserted on radio that 'this campaign has been made for the satirists' (ABC 2010). From our observation of the editorial cartoons of the campaign, the level of engagement with significant issues was too slight even for the satirists to get much of a handle on events. Indeed, it was only the ABC TV show Gruen Nation that broke new satirical ground in this campaign, and that was because it focused on the advertising and spin rather than the political substance. It debuted in its election mode with an audience of 1.6 million, 'winning' the night against the commercial channels, and developed a strong following for the quality and wit of its attack on election advertising (The Sunday Age, 1 August 2010). The success of this meta-analysis of the political game reflects the trouble satirists in more traditional modes had in finding anything much to grasp. Wright was only half-right about the campaign for the cartoonists; it was a joke for them, certainly, but mostly a rather bad and empty one.

They had to rely a lot on physical caricature of the leaders, as there simply was not much more to work with than a woman with red hair and a big nose up against a man with big ears often photographed coming out of the surf in his 'budgie smugglers' (or bathers). The major parties did differ on some key policies, such as the virtue or otherwise of a mining tax, how to deliver Internet services to the nation, and how generous parental-leave provisions might be, but for many voters (the cartoonists included), these appeared rather insignificant when compared with the issues in recent elections. For the most part, Tony Abbott and Julia Gillard seemed keen to empty their own campaigns of policy content in the hope of slipping into office by dint of being less scary than the other party in the eyes of a majority of swinging voters. As Gillard put it in what might actually have been an unguarded moment: 'If you are looking for a prime minister with small ears, this is not your election' (The Australian, 18 August 2010). It would have been a good joke if one could be certain it was a travesty of clearly understood political differences. For many, however, it must have seemed a metaphor for the lack of significant choice on offer. The cartoons of this campaign brought to mind those of 1998-another election when a struggling first-term government was opposed by a small-target Opposition, 
and where the theme of the cartoons could be summarised as 'Australia deserves better' (Manning and Phiddian 2000). As the grandfather of current Australian cartoonists, Bruce Petty, shows, it was a long struggle to the polls for the voters and (by extension) for the cartoonists.

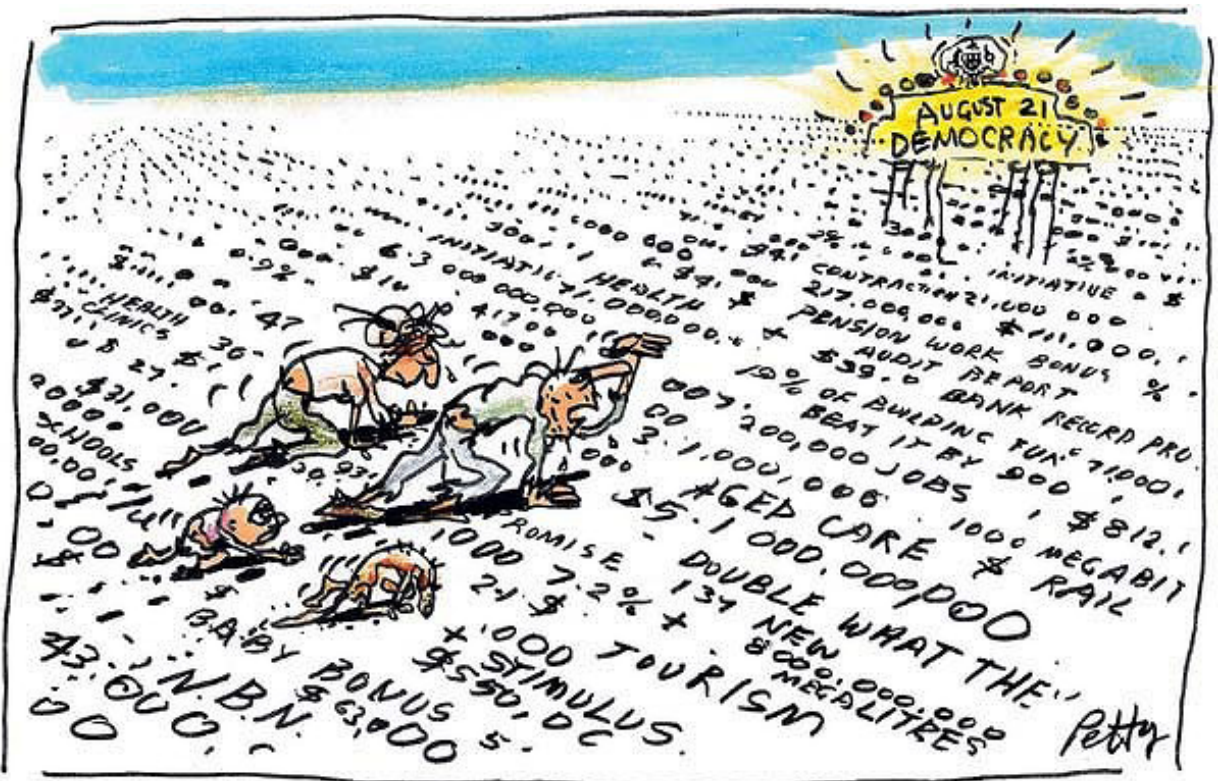

Figure 8.1 Bruce Petty, The Age, 16 August 2010

Democracy matters, this reminds us, even when it is arduous. Surely, it should be better than this? Two cartoons illustrate the basic negativity of this campaign, and point to the eerily symmetrical 'curse on both your houses' that almost suggested the result voters delivered on polling day.

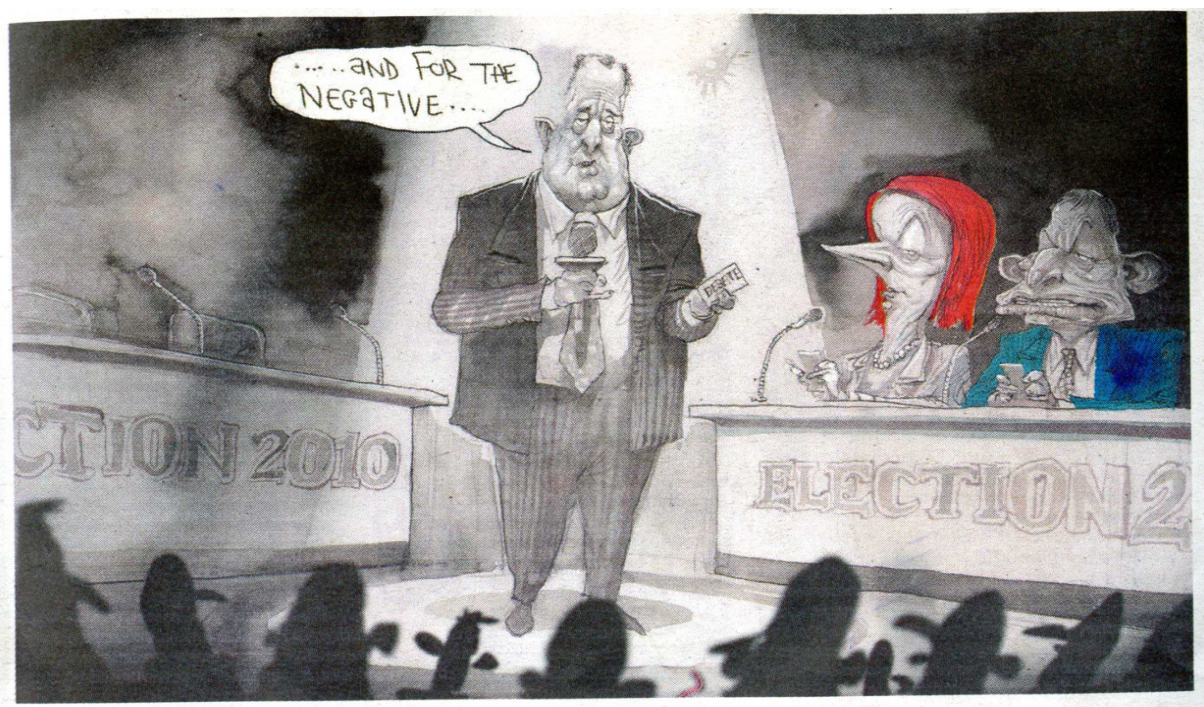




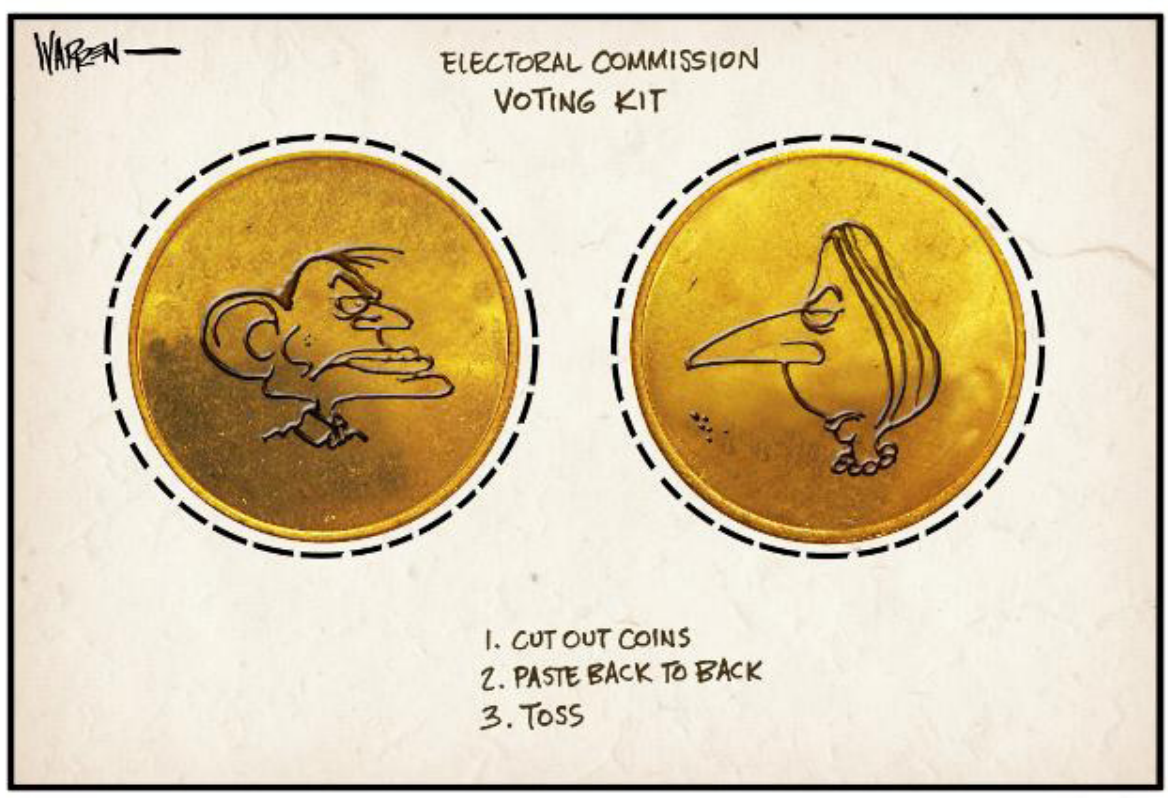

Figure 8.3 Warren Brown, The Daily Telegraph, 18 August 2010

The key theme in the cartoons that follow is voter disillusionment at two opposing leaders battling for attention when their platform and policies were demonstrably thin compared with campaigns in recent decades. Cartoonists tend to personalise and caricature issues, and they tend to focus particularly on the leaders of the major parties during the campaign. Our sample of all the cartoons appearing on the nation's capital-city daily newspaper editorial pages demonstrates this, although the presence of two former Labor leaders, Kevin Rudd and Mark Latham, provided some relief from the usual focus on the Prime Minister and the Opposition Leader.

For reasons that differed partially for each major party, negativity predominated in both campaigns. We will trace this through the cartoons, starting with the particular difficulties Labor faced in campaigning without being able to mention its achievements. After taking the prime ministership in extraordinary circumstances, Gillard said: 'I talked to many of my colleagues, and obviously my colleagues formed the same view I did that... a good government had lost its way. It was necessary to get the government back on track with me as prime minister' (The Age, 26 June 2010). Crafting a campaign based on an oxymoron of such profound dimensions was never going to be easy, and a messy campaign did indeed transpire for Labor.

Opposition Leader, Tony Abbott, was provided with plenty of ammunition but his cautious demeanour, constant negative carping and lack of economic 
knowledge meant his moment of mid-campaign dominance was only short lived. We will conclude by showing how some cartoonists predicted the evenness of the final result and commented pointedly on the insignificance during the campaign of important issues such as the rise of the Greens and environmental and Indigenous policies.

\section{ALP Campaign}

The Sydney Morning Herald cut to the quick in pointing to the difficulty that would so hamper Labor's campaign - namely, that they were a government with no choice but to stand on their record, while at the same time repudiating the recently deposed leader and implicitly supporting the general view of the Rudd Government as all talk but too little action.

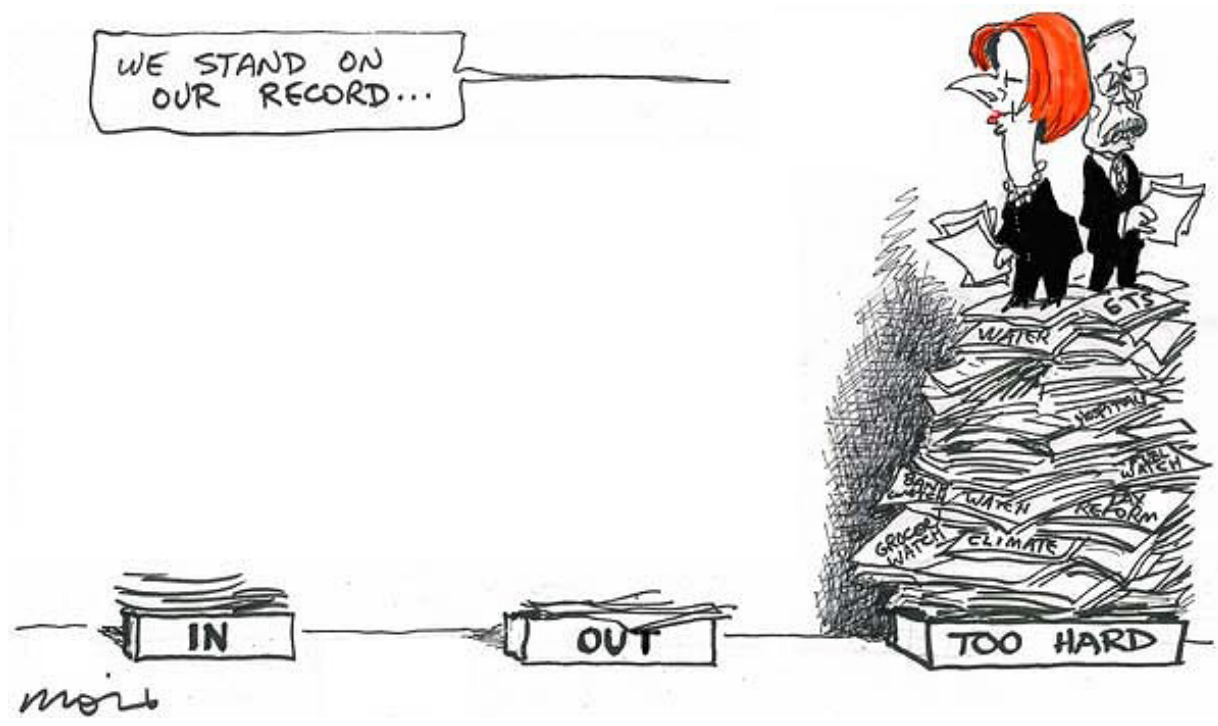

Figure 8.4 Alan Moir, Sydney Morning Herald, 11 August 2010 
The specific retreat from Rudd's rhetorical embrace of a big Australia to much hazy talk of what might constitute a 'sustainable population' and some associated dog whistling about there being too many migrants left cartoonists bemused, the general public confused and fourth-estate elites - particularly those writing for the Murdoch press - aghast. There can be no doubt Gillard's tilt at populism through variations on the term 'sustainability', which is often now little more than an appeal to anything and everything that might sound environmentally progressive, was one of the campaign surprises. Abbott announced that he shared Gillard's hostility to rising population rates, and was not keen to defend the tradition he inherited from Howard. As in the 2001 campaign, both leaders tried to outdo each other in their sympathy for those who felt pressured by immigration, as Nicholson points out.

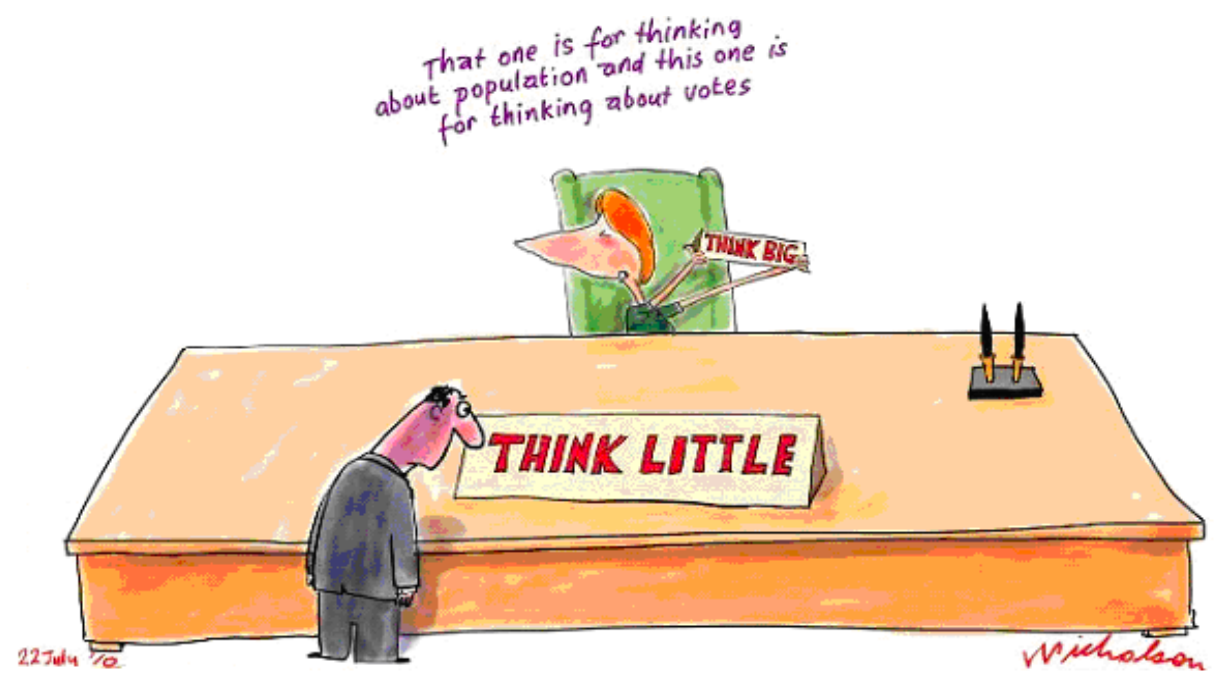

Figure 8.5 Peter Nicholson, The Australian, 22 July 2010

After a fairly good opening week of campaigning, Gillard's second week fell apart when journalist Laurie Oakes reported he had received 'in confidence' information that, during Cabinet deliberations, she had opposed paid parental leave and questioned the size of a pension rise proposal. Cartoonists seized upon this news, as nothing quite beats conjecture about who might be the source of a leak. Suspicion fell upon the recently deposed prime minister, who now found himself well and truly back in the picture. 


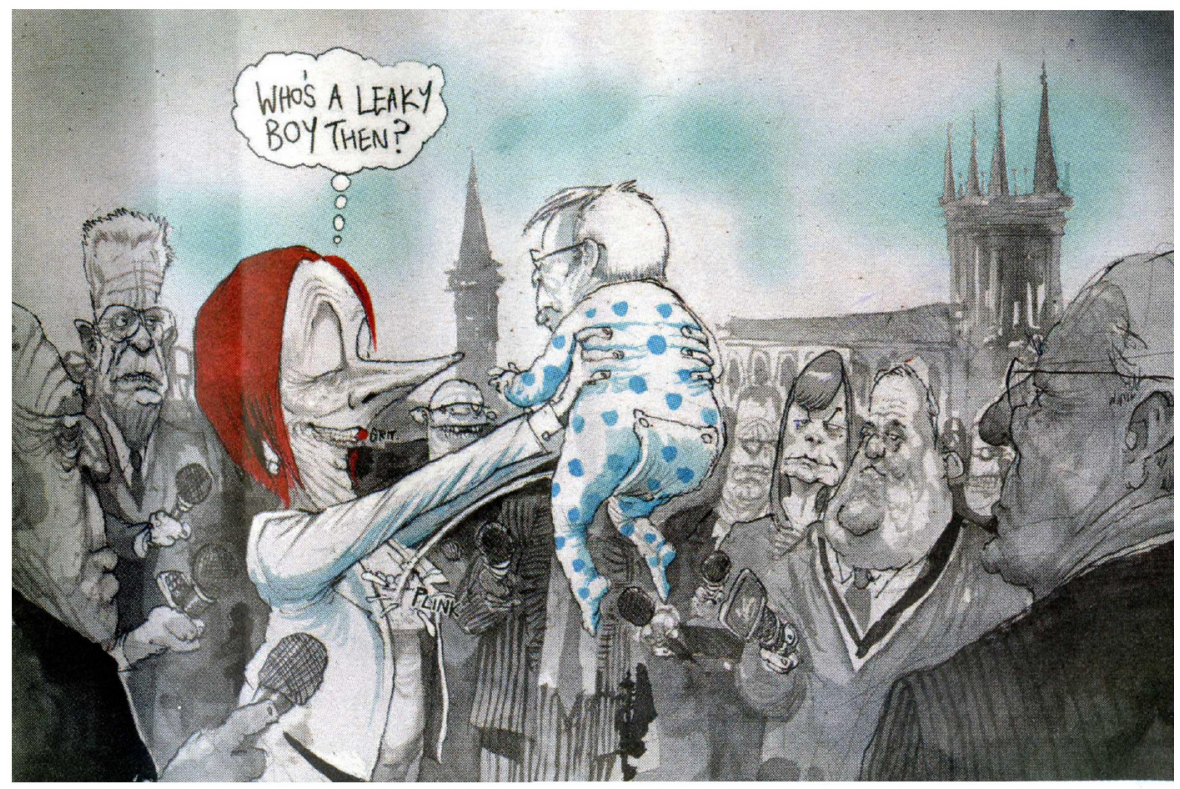

Figure 8.6 David Rowe, Australian Financial Review, 29 July 2010

The main upshot of these damaging leaks, combined with the prospect of more to come, was a truly remarkable twist to modern campaign strategy. The newly minted Prime Minister announced that she had had enough of the traditional finely honed campaigning and from now on would 'throw that rule book out and really get out there'; as she said, 'it's time for me to make sure that the real Julia is well and truly on display' (The Canberra Times, 3 August 2010; The Advertiser, 2 August 2010). With the announcement of the 'real Julia', cartoonists had a field day - cruelly and accurately suspecting they were observing yet another layer of spin. This proposition is elegantly summarised by Warren Brown. 


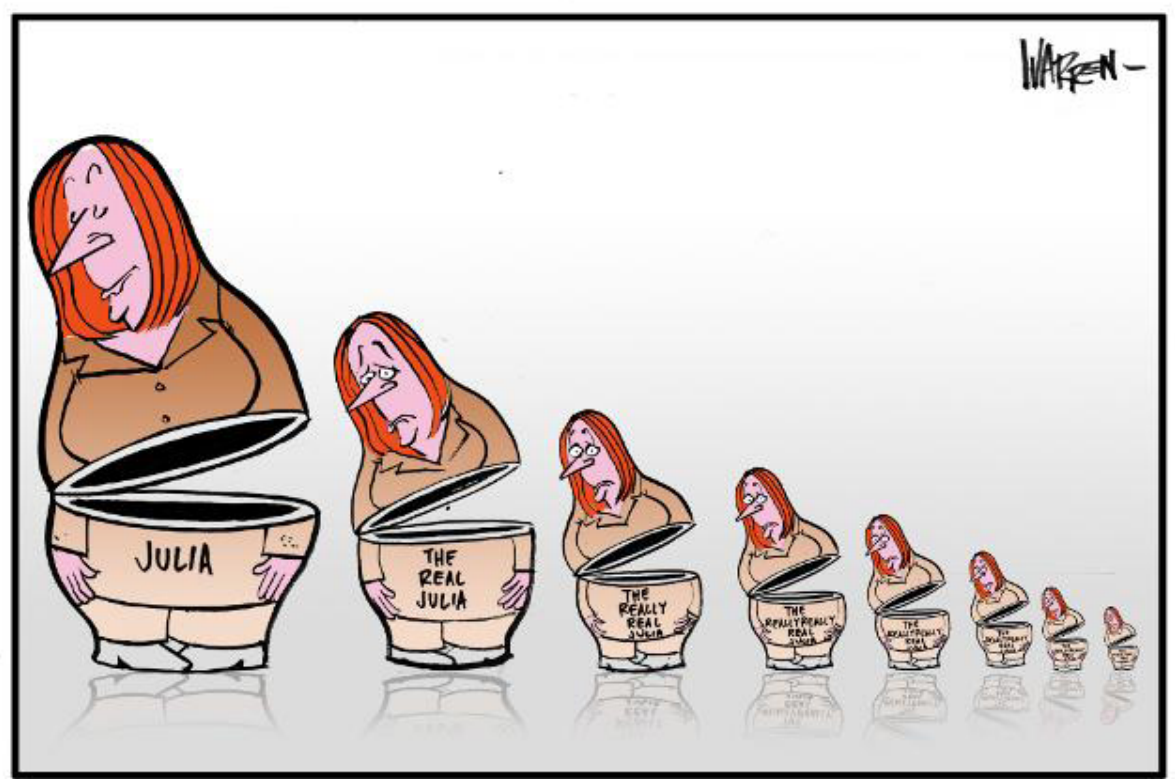

Figure 8.7 Warren Brown, The Daily Telegraph, 5 August 2010

Whether the 'real Julia' line was really spin or substance, Gillard's moment of critical self-reflection served a good purpose in opening the way to one of the real innovations in the 2010 campaign. To prove how real she was, Gillard was suddenly determined to debate Abbott again, and he used his unexpected position of power to extort a new format out of his opponent: the 'town-hall debate'. While there is no doubting that this format played to his strengths, it is also arguable that it is a welcome democratic innovation in otherwise stagemanaged campaigns. The cartoonists were not immediately convinced, with Mark Knight questioning the degree of engagement from the punters at the Rooty Hill RSL Club meeting where both leaders refused to appear simultaneously. It, and a follow-up event in Brisbane, did, nevertheless, break the mould of past campaigning by allowing for this more authentic interaction with citizen voters. 


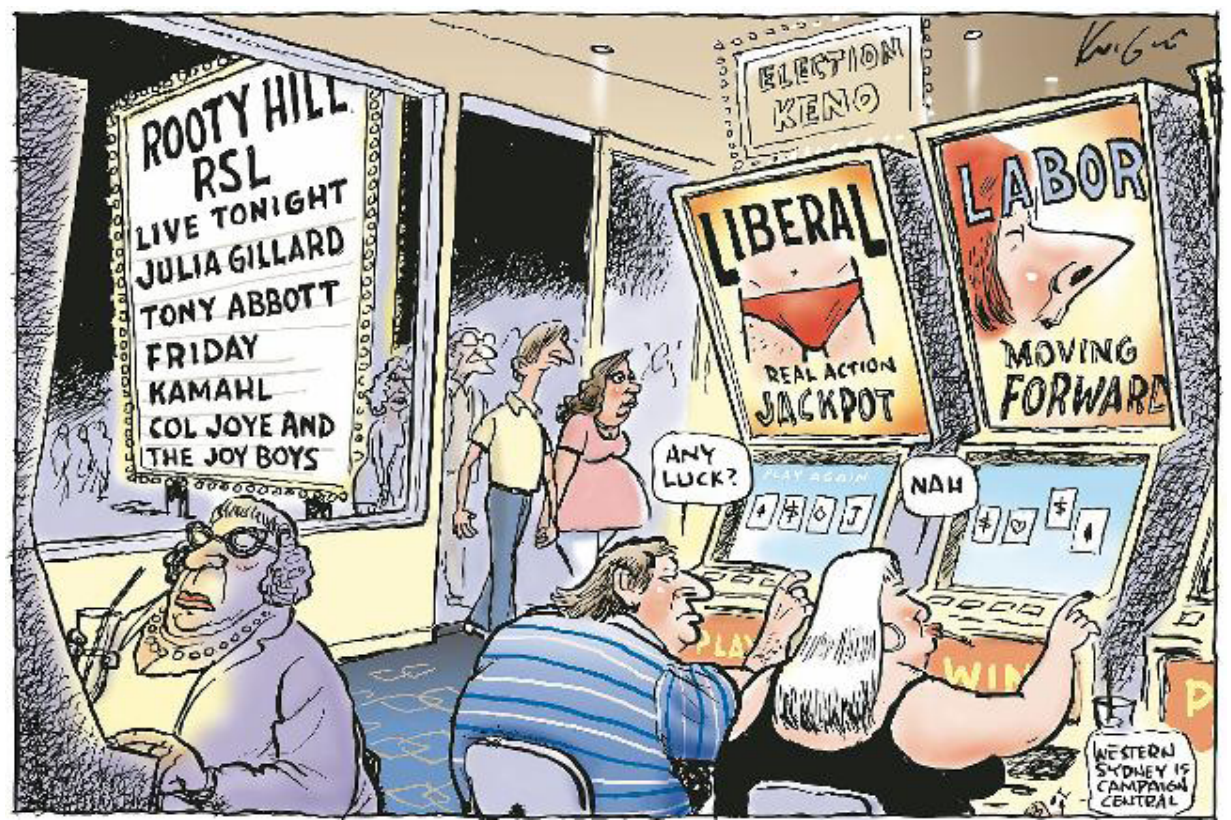

Figure 8.8 Mark Knight, Herald Sun, 12 August 2010

After the leaks forced Gillard's shift in strategy, any prospect of clear space to pump out the daily campaign message was further confounded when Rudd was hospitalised with a serious gall-bladder ailment. Cartoonists seized on the image of a deposed leader with a gall overload and questions of how 'sorry' Gillard might be for his discomfort. Then another former Labor leader, Mark Latham, captured national attention by sidling up to Gillard at Brisbane's annual agricultural show and, in an intimidating manner, questioning her about a complaint he thought she had made to the Nine Network about his working for them as a journalist. Latham also urged Gillard to expose Rudd's supposed duplicity as the source of Oakes' information. Labor's campaign looked decidedly derailed and in a state of despair, as Rowe and Knight so subtly point out. 


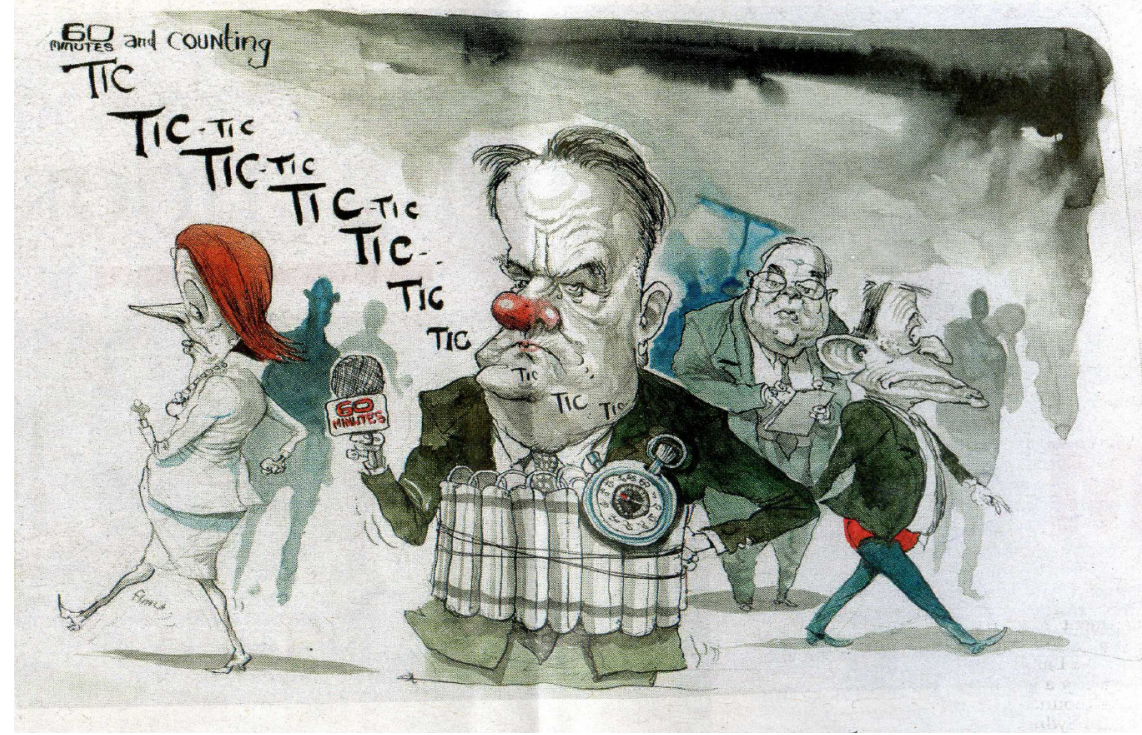

Figure 8.9 David Rowe, Australian Financial Review, 13 August 2010

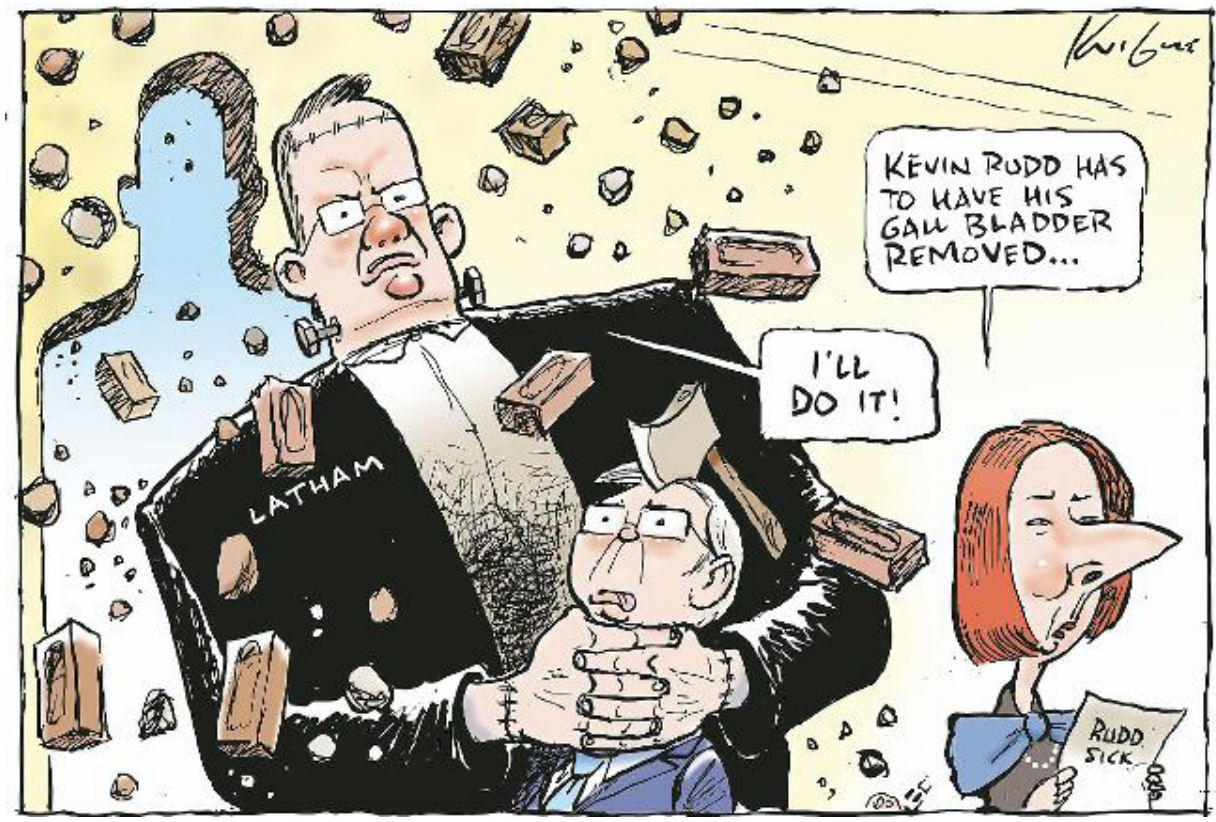

Figure 8.10 Mark Knight, Herald Sun, 31 July 2010 
Finally, Labor's risibly late 'campaign launch' — well into the final weekbrought this corrosive accusation of pointlessness from Alan Moir.

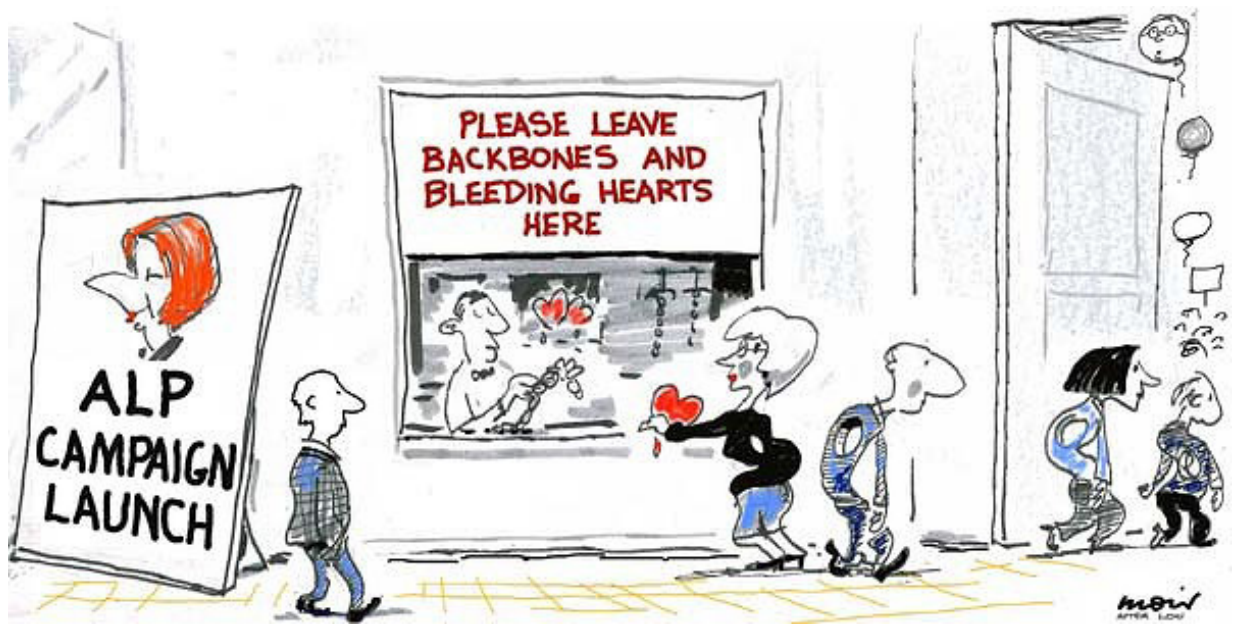

Figure 8.11 Alan Moir, Sydney Morning Herald, 17 August 2010

The 'true believers' had great difficulty getting excited by the Labor campaign at any point, even while most pundits continued to believe that they would survive as a government.

\section{The Coalition Campaign}

The Coalition campaign was clearly much more disciplined and 'on message' than Labor's. Apart from Abbott's difficulties explaining his policy on national broadband networking, there were relatively fewer cartoons poking fun at Abbott's campaign when compared with those aimed at Gillard. Interestingly, it was Rudd who made one of the more telling critiques of Abbott's campaign when he observed that '[t]here is a real danger at present because of the rolling political controversy about myself that $\mathrm{Mr}$ Abbott is simply able to slide quietly into the office of Prime Minister' (Gordon 2010). For the most part, cartoonists turned out similar caricatures of Abbott as an obsessed fitness fanatic perpetually dressed in only his swimming gear, and these became quite formulaic by campaign's end. Golding employs this caricature to make a further point that the opinion polls suggested a large gender divide had emerged, with women voters wary of Abbott. Worried by the prospect, Abbott employed his wife and daughters for as many photo opportunities as possible. 


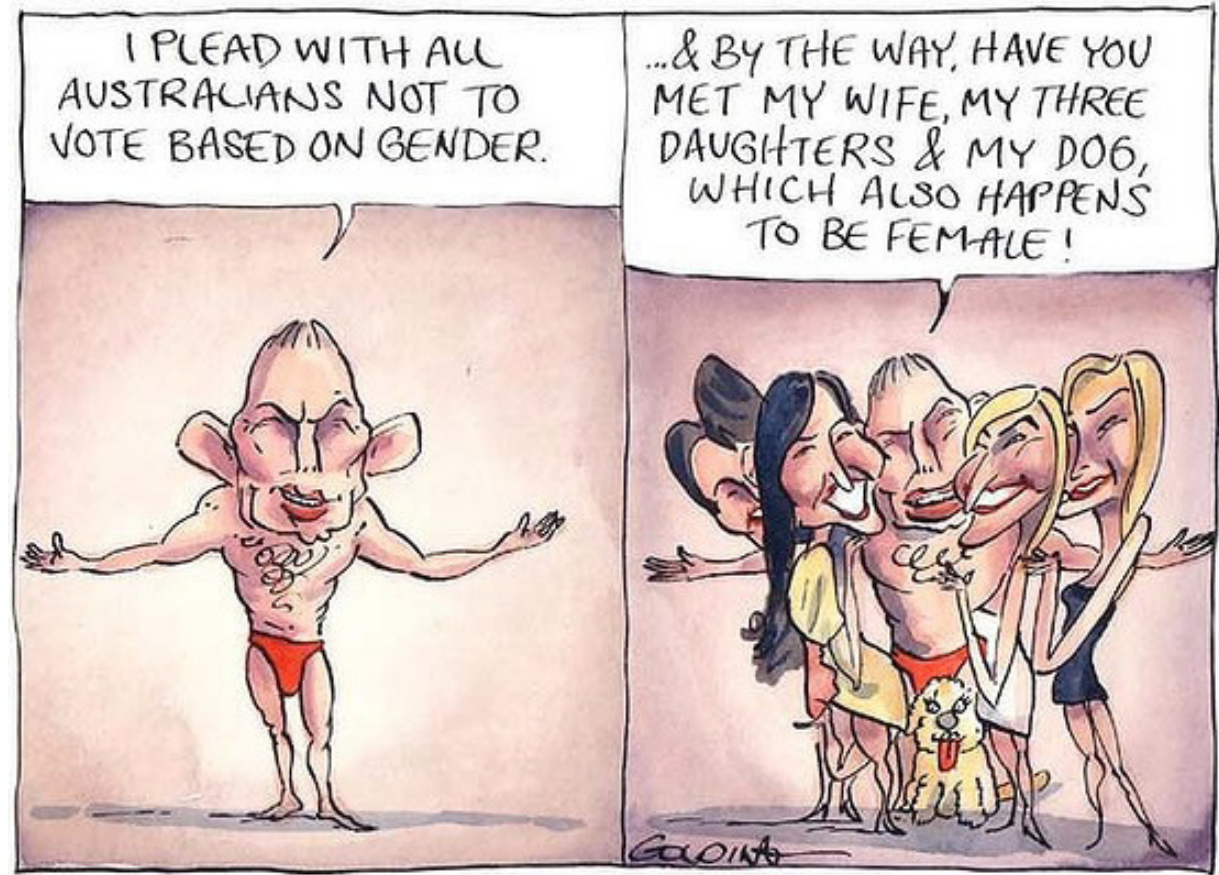

Figure 8.12 Matt Golding, The Age, 1 August 2010

The 'cartoonable' rough edges of the Coalition's campaign were most evident in their disarray over the costings of their promises. This raised questions about their economic credibility and was emphasised by the steady eclipse of the Shadow Treasurer, Joe Hockey, by the technically junior finance spokesman Andrew Robb.

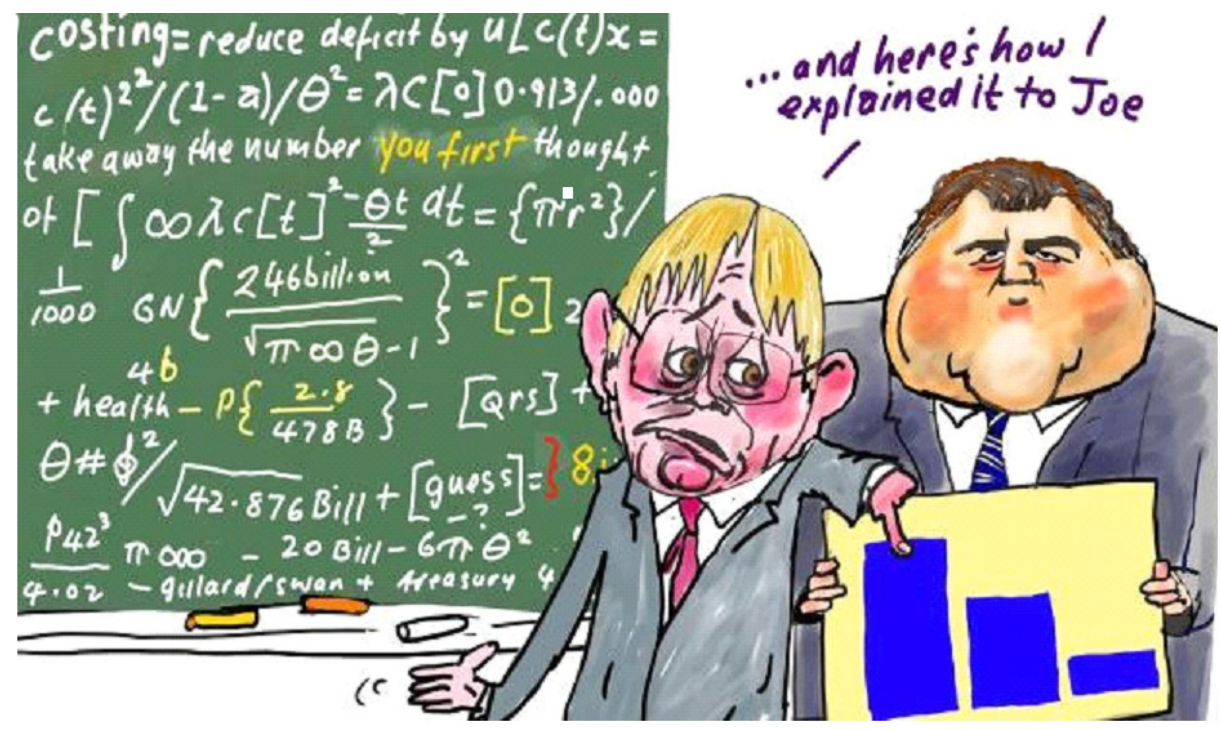

Figure 8.13 Peter Nicholson, The Australian, 19 August 2010 


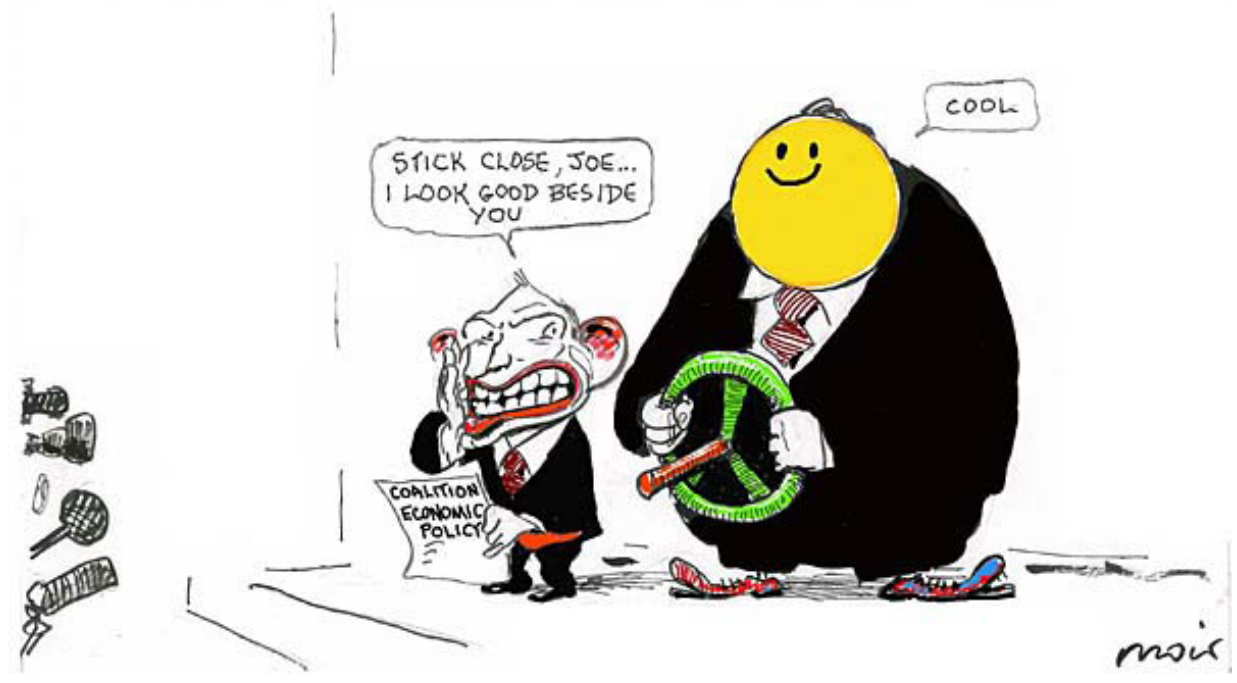

Figure 8.14 Alan Moir, Sydney Morning Herald, 18 August 2010

Abbott himself deferred to these two on economic matters and, as noted above, he also had some trouble with his broadband proposal. The Coalition's policy on this matter might have been less wasteful, but it was certainly trumped by the grandeur of Labor's plan for a national network built upon optical fibre. It would transpire that this piece of product differentiation was crucial after the election in deciding the votes of three regional Independent MPs, and Sean Leahy's cartoon illustrates the fact that Abbott never looked in command of the issue or its implications for the future. 


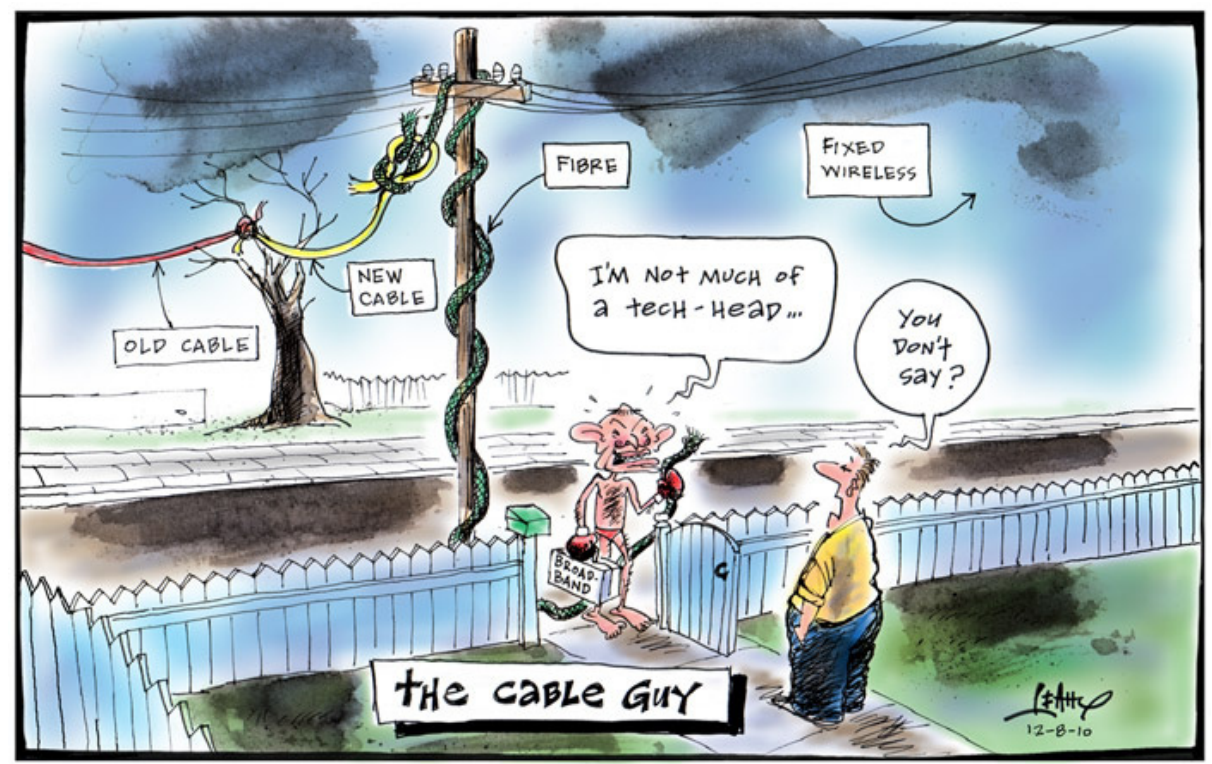

Figure 8.15 Sean Leahy, The Courier-Mail, 12 August 2010

\section{Common Ground}

The most obvious thing about the 2010 cartoons as a group is the extent to which they were dominated by the leaders, their images and machinations about tactics such as the endless dispute over the number and format of debates. Andrew Dyson neatly summarises the image primping - picked up particularly because of Gillard's appearance in a spread in the Women's Weekly, and capitalising on Abbott's long-term propensity to be photographed shirtless during hard physical exercise. 


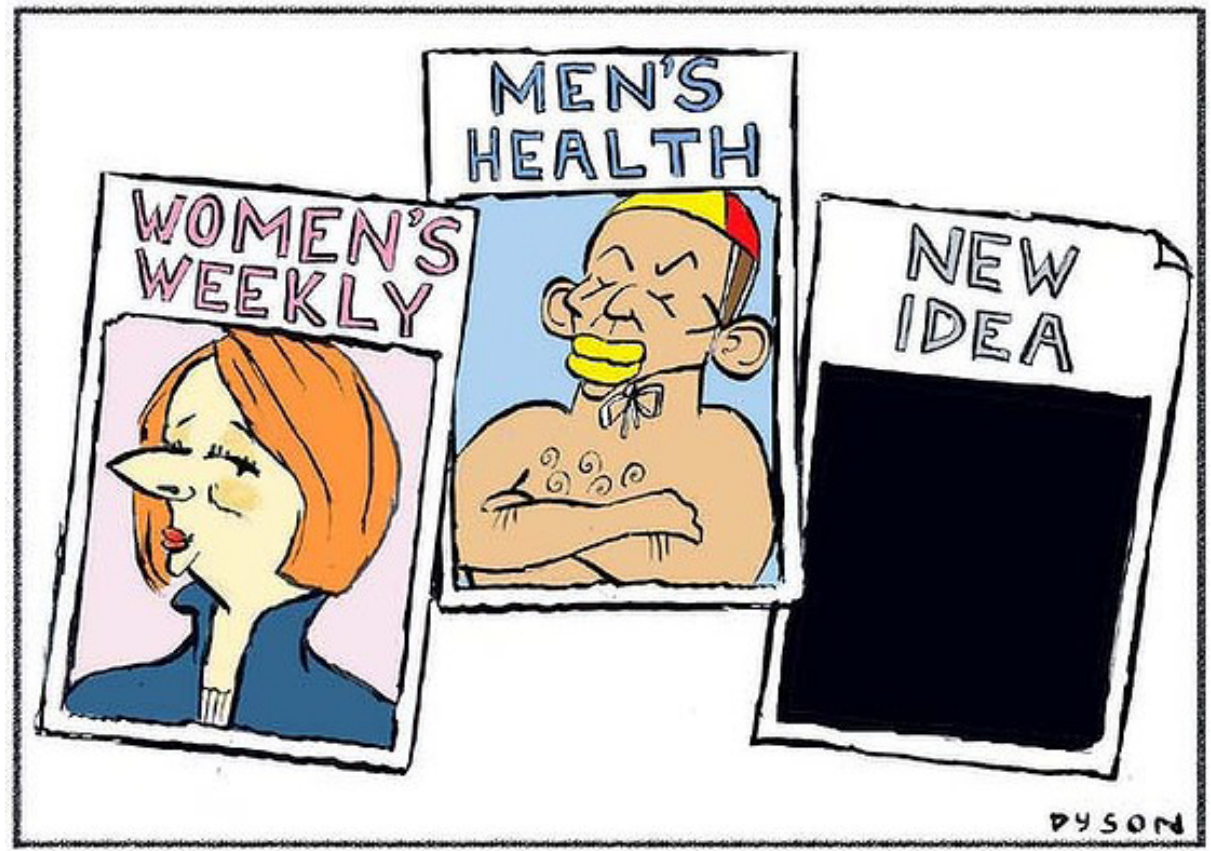

Figure 8.16 Andrew Dyson, The Age, 29 July 2010

Two points are worth making about the cartoon's focus on the two leaders. One is that, while leaders always dominate the image count, it was particularly so this time. This might well reflect the extent to which both Gillard and Abbott sought to draw attention to unpopular policies their opponents were associated with when ministers. For Gillard, it was the constant and obsessive attack on Abbott's supposed secret plans to reintroduce WorkChoices. For Abbott, it was the opportunity to chastise Gillard over rorting surrounding the Building the Education Revolution, plus her close association with Rudd's prime ministership as part of the so-called 'Gang of Four' whom many felt had displaced Cabinet decision making. These attacks - though focused on policy more than personality - too often caused the campaign to take on a snarling tone. The other point is that we found nothing systematically sexist in the representation of Gillard. She was caricatured-sometimes harshly-but her gender was, if anything, less often the focus of attention than Abbott's. If we are right, this supports Manning's earlier work (2008) on sexism in cartoons, and marks a small victory for equality. 
A strong suite of cartoons focuses on one of the more nearly substantive debates of the campaign: the complicated situation concerning population size and both leaders' preparedness to doubt the decades-long bipartisan commitment to the so-called 'big Australia'. Much to the irritation of the business elite and many economists, Gillard and Abbott recognised that ordinary voters feel pressured in their daily lives by a growing population that in many suburbs is serviced inadequately by infrastructure. While these are innocuous enough as a set of observations, the leaders tended to conflate this matter with the problem of asylum-seekers arriving in boats. This never quite explicit connection of ideas became a proxy for conveying sympathy for voters living in middle to outer suburbs, especially the fabled land of western Sydney. Pope, Leak and Moir all found this politicisation of desperate people ethically dubious.

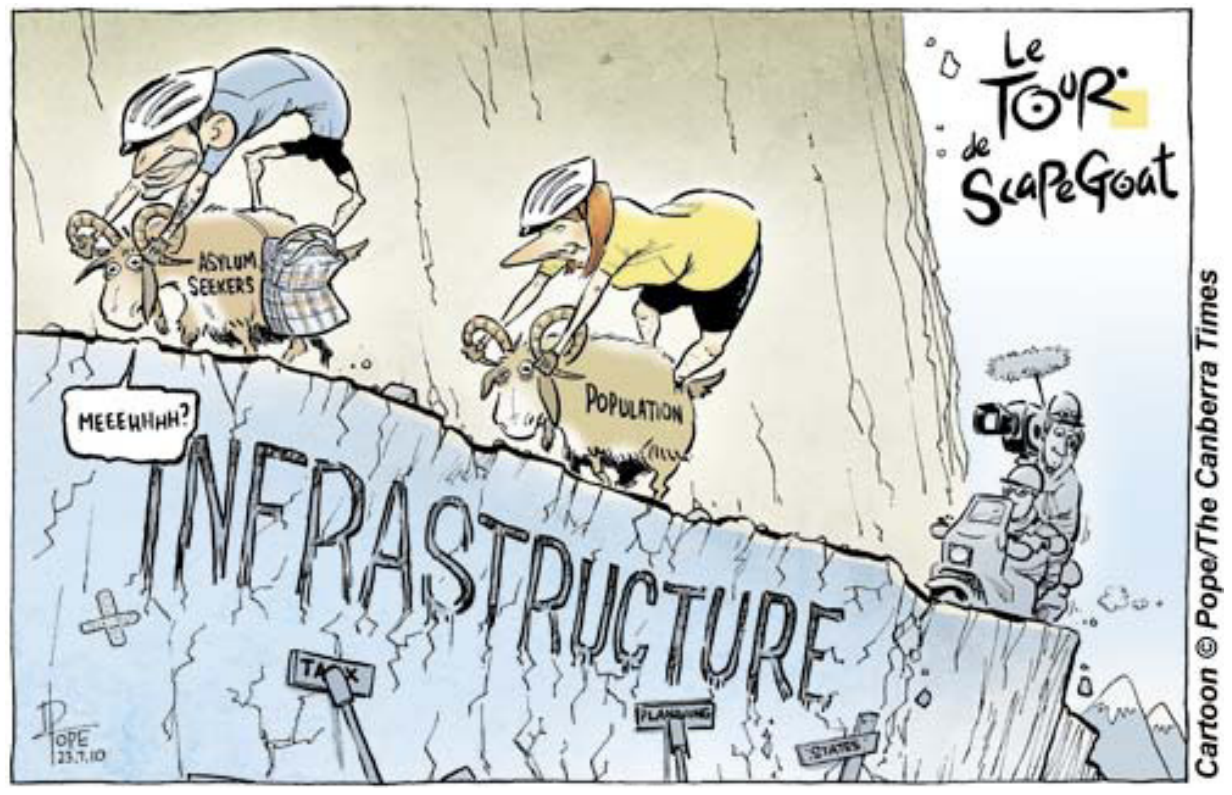

Figure 8.17 David Pope, The Canberra Times, 23 July 2010 


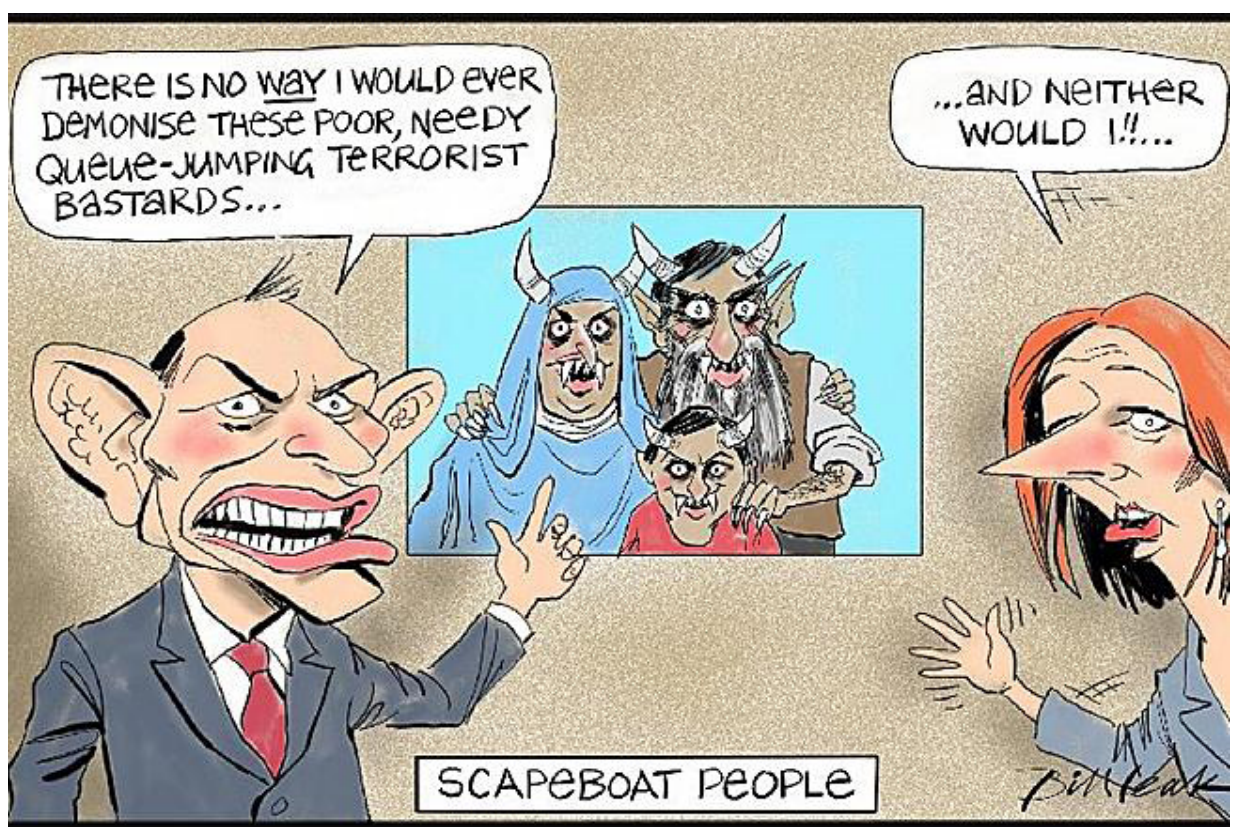

Figure 8.18 Bill Leak, The Australian, 20 July 2010

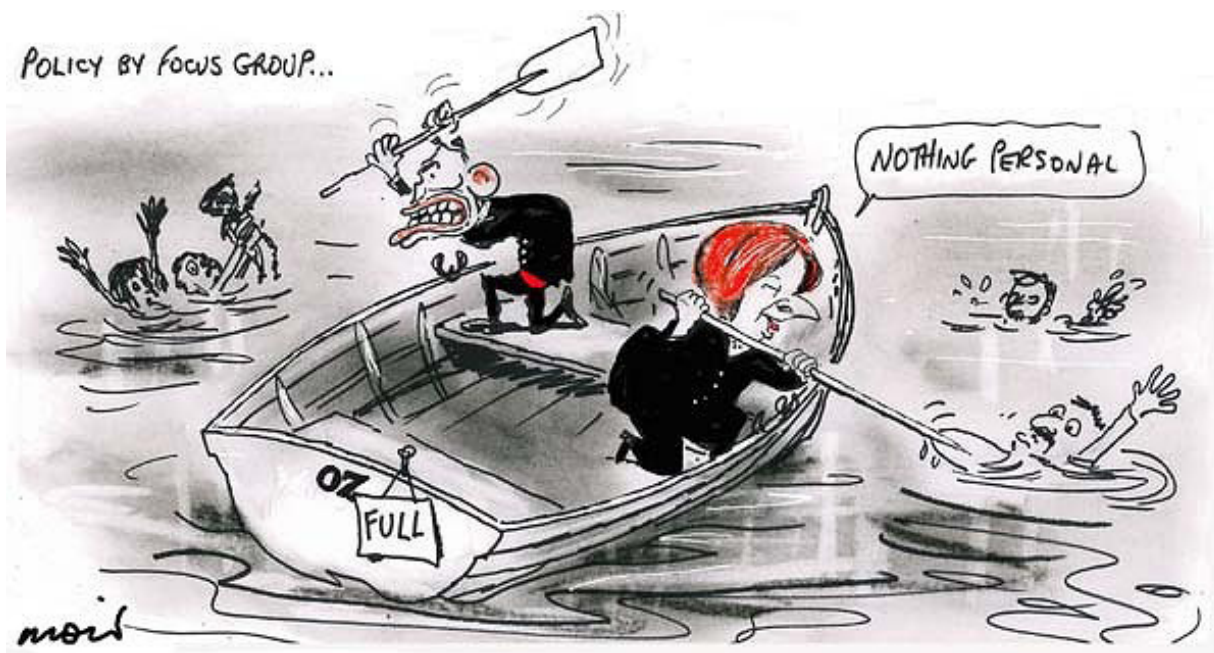

Figure 8.19 Alan Moir, Sydney Morning Herald, 29 July 2010

In tune with the great cartooning cry of opposition in 2001 (the 'Tampa election'; see Manning and Phiddian 2002), this time, the cartoonists made a clear and valid accusation of scapegoating. The conclusion to draw from all this appears to be that an election campaign is not the best time to start a debate over something as complicated as population size. In practice, both leaders were rejecting one of Rudd's last prime ministerial thought bubbles - an expression of faith in a 'big Australia'. Clearly, without a prolonged pushing of the policy wagon in 
the years between elections, the sudden broaching of such issues runs the risk of drifting into appealing to nascent fears of many voters that immigration is 'getting out of control'. The alternative of growth by stealth-apparently preferred by an unusual coalition of business and cultural elites - seems little better than fearmongering from a democratic point of view.

Finally, some of the established elements of staged campaign conflict were becoming increasingly obvious as charades. Not only were the official campaign launches absurdly late in the piece (and consequently empty of content), the official leaders' debate was upstaged by a cooking show. After the usual charade with the Opposition Leader calling for more than one debate and the incumbent Prime Minister refusing to entertain such a proposition, the event failed to attract an audience of any consequence. Even after the debate was moved forward an hour to avoid clashing with the series final of MasterChef, it remained an object of bemusement to those voters who bothered to watch it.

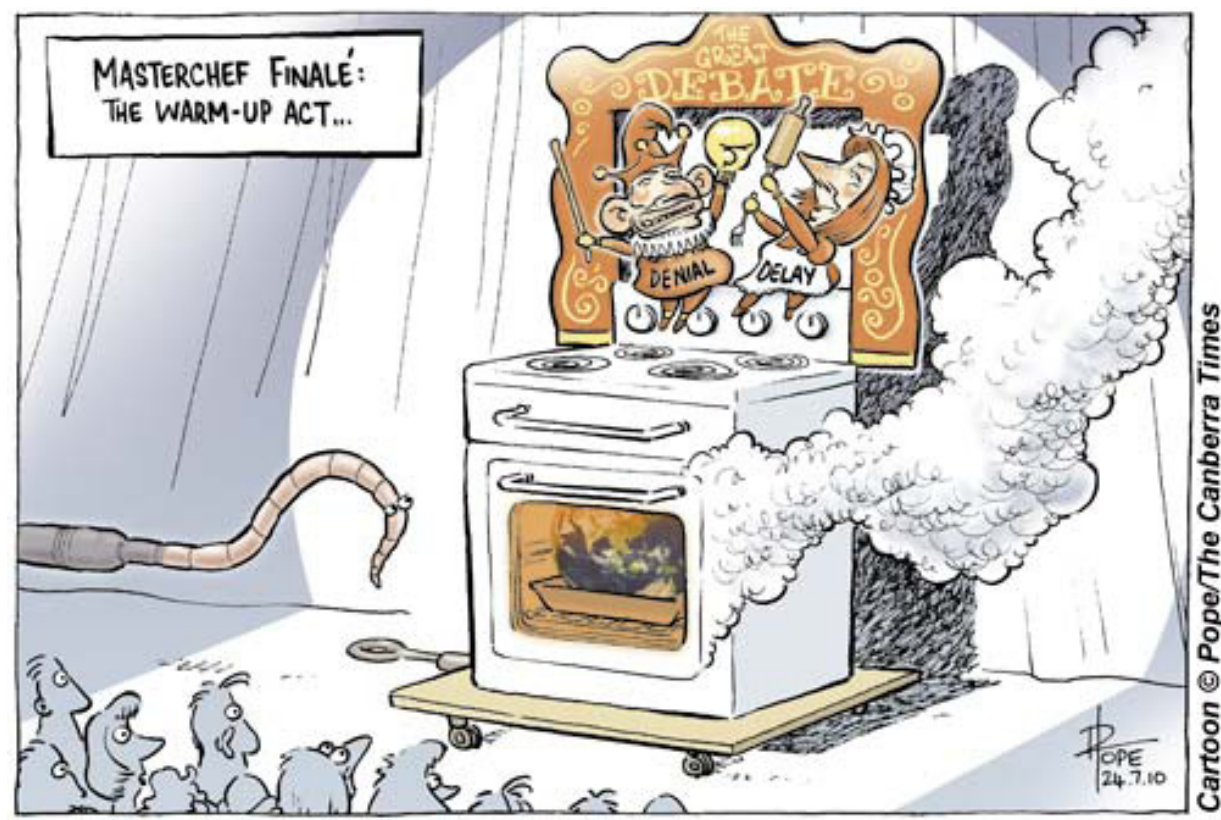

Figure 8.20 David Pope, The Canberra Times, 29 July 2010

\section{Almost Missing Links}

The main focus of the campaign in the cartoons was the uninspiring spectacle of a machine-politician prime minister trying desperately to simulate convictions confronting an Opposition leader assiduously trying to suppress the evidence of his lifetime of conviction politics. Nevertheless, satirists seized on a couple 
of issues of real significance that largely slipped underneath the campaigning radar. For example, apart from a couple of cartoons, there was precious little discussion of Aboriginal Affairs, as Moir acerbically points out.

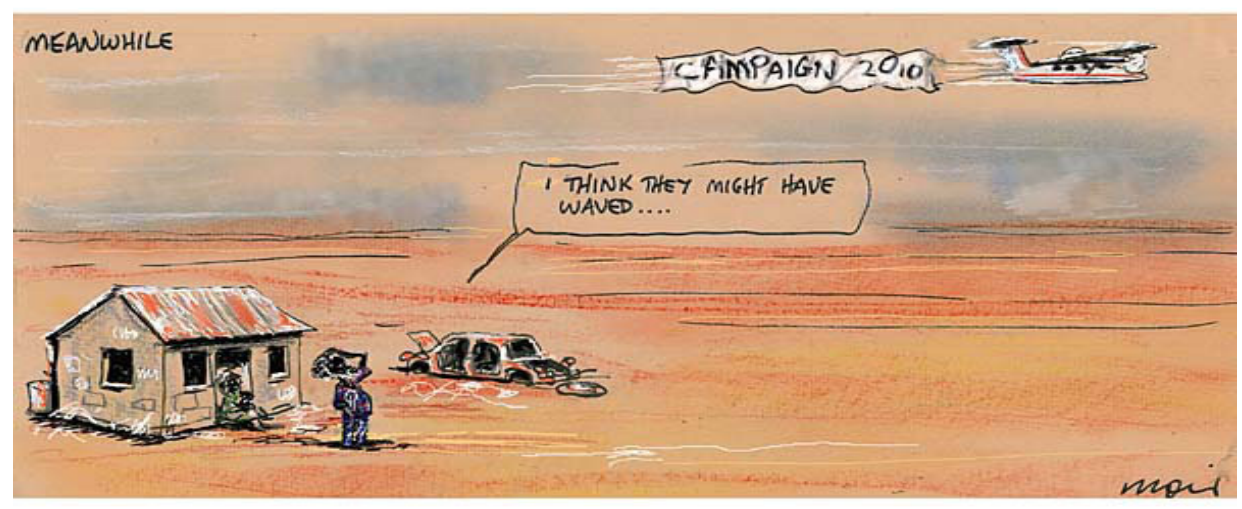

Figure 8.21 Alan Moir, Sydney Morning Herald, 27 July 2010

Similarly, The Chaser's Yes We Canberra on ABC TV also hammered the selfindulgence (even the self-pity) of much of the campaign subject matter with a weekly segment in which Indigenous people were filmed in Arnhem Land commenting patronisingly on the campaign's machinations. It was a severe yet strangely cheerful comment on white, middle-class self-absorption, and neglect of real and urgent social issues.

Another missing link - all the more remarkable given that everyone (rightly) assumed that the Greens would come out of the election with at least the balance of power in the Senate - was the dearth of discussion of the Greens and most notably the question of putting a price on carbon during the next term. There was also little talk about the even more pressing issue of water for agriculture and environmental river flows. Both major-party leaders were happy to skate around the carbon question and were doubtless relieved to find that the Murray-Darling Basin Authority said it would delay release of its 'plan' - a document with potentially divisive recommendations. Given the urgency and prominence of water politics in South Australia, The Advertiser struck a chord with its aggrieved audience. 


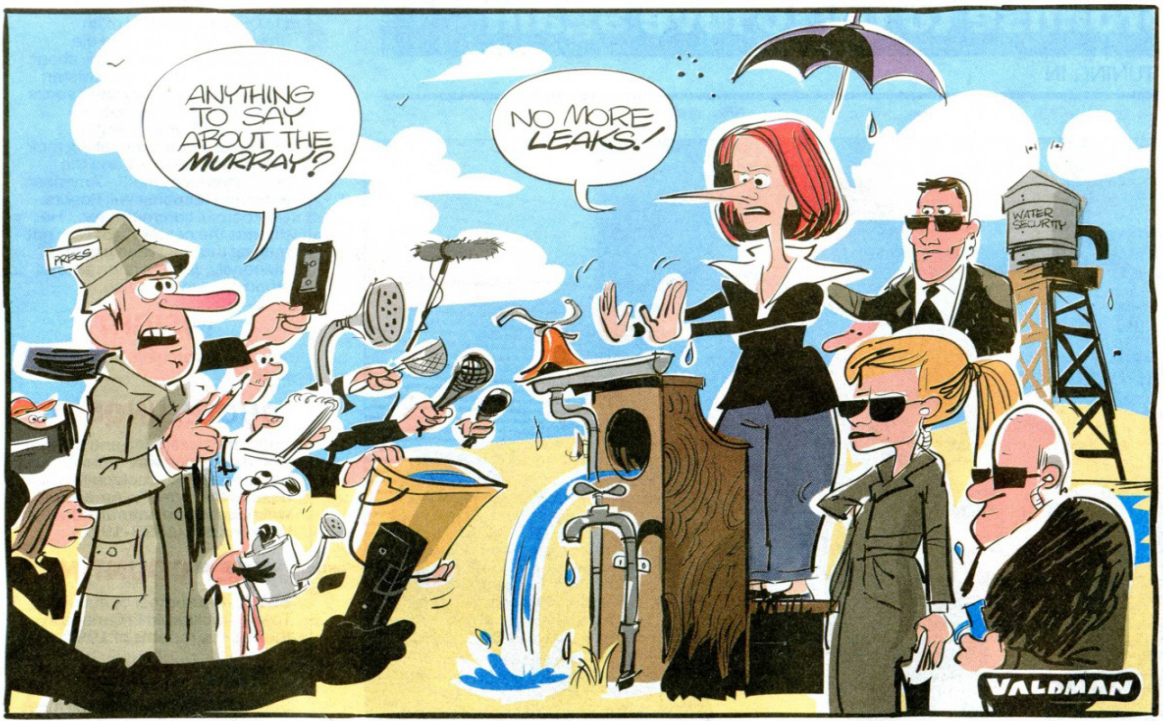

Figure 8.22 Jos Valdman, The Advertiser, 29 July 2010

The broader implications of growing Greens support were remarked on by John Spooner-often one of the most satirical observers. He reminds us that something major was happening and that joy on election night was less likely to visit Abbott or Gillard than it was the Greens leader, Bob Brown.

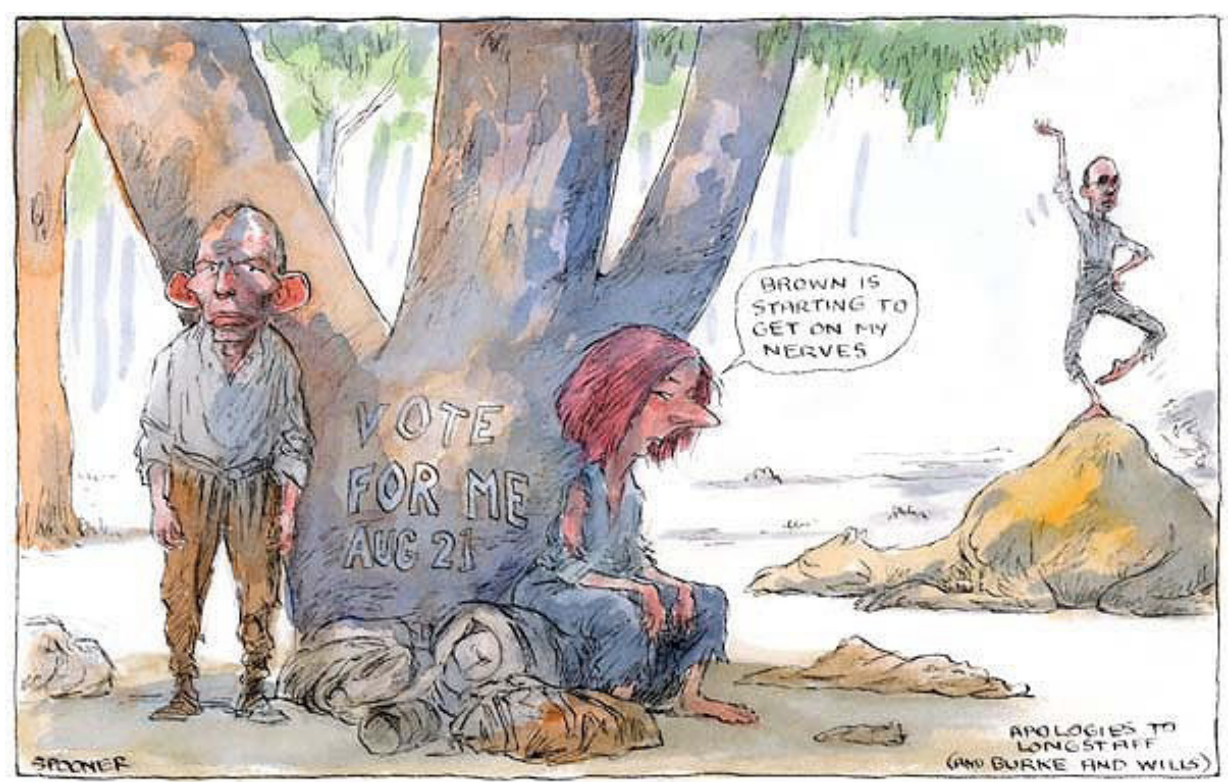

Figure 8.23 John Spooner, The Age, 21 August 2010 


\section{The Election Result and Aftermath}

Sean Leahy in The Courier-Mail was - as far as we know - the first commentator of any kind to predict (as opposed to contemplate) a hung parliament. Perhaps his position in Queensland permitted him to sense that there was a bigger move on than other commentators envisaged.

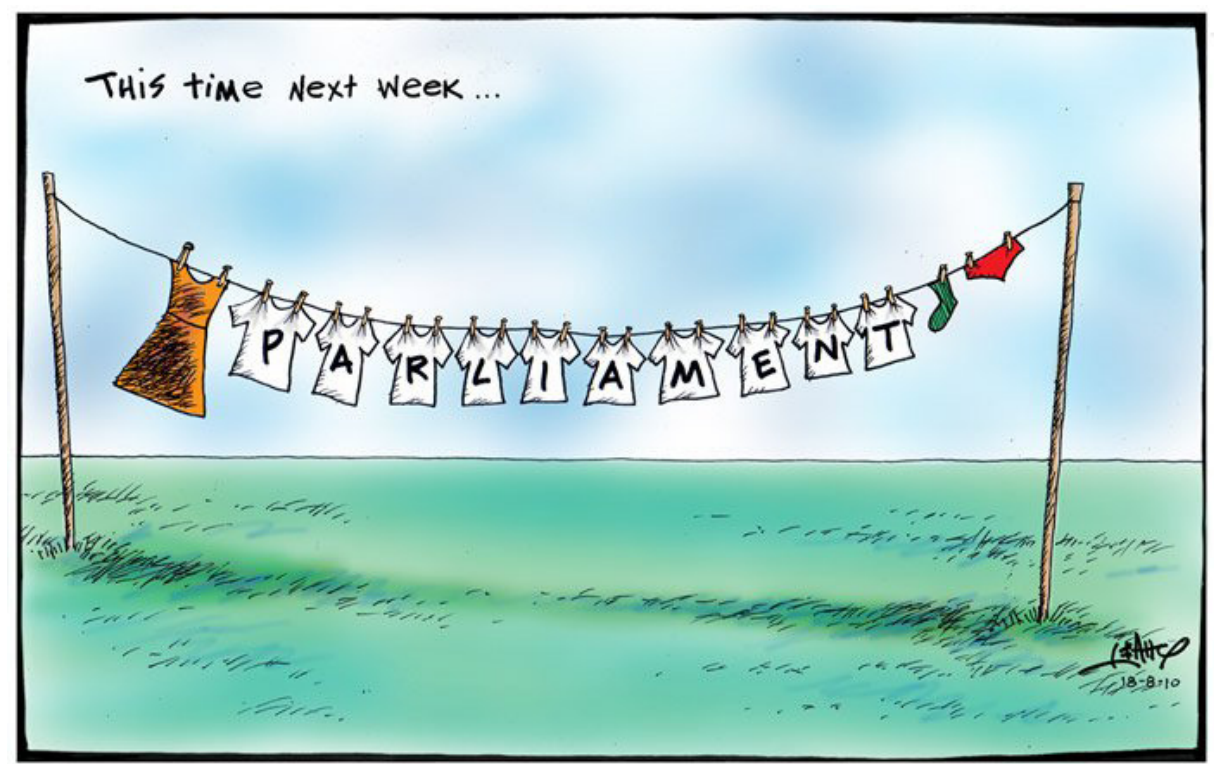

Figure 8.24 Sean Leahy, The Courier-Mail, 18 August 2010

All pundits were instantly wise after the fact but, as usual, some of the best autopsy came in the cartoons. The week after the election provided some wonderfully incisive cartoons, of which we give only two examples that, we think, capture the mood of the moment precisely. Moir presents the sudden power of the rural Independents, and Nicholson deploys a strange pathos in his depiction of Labor's 'faceless men', who live only for electoral success and had clearly failed. 


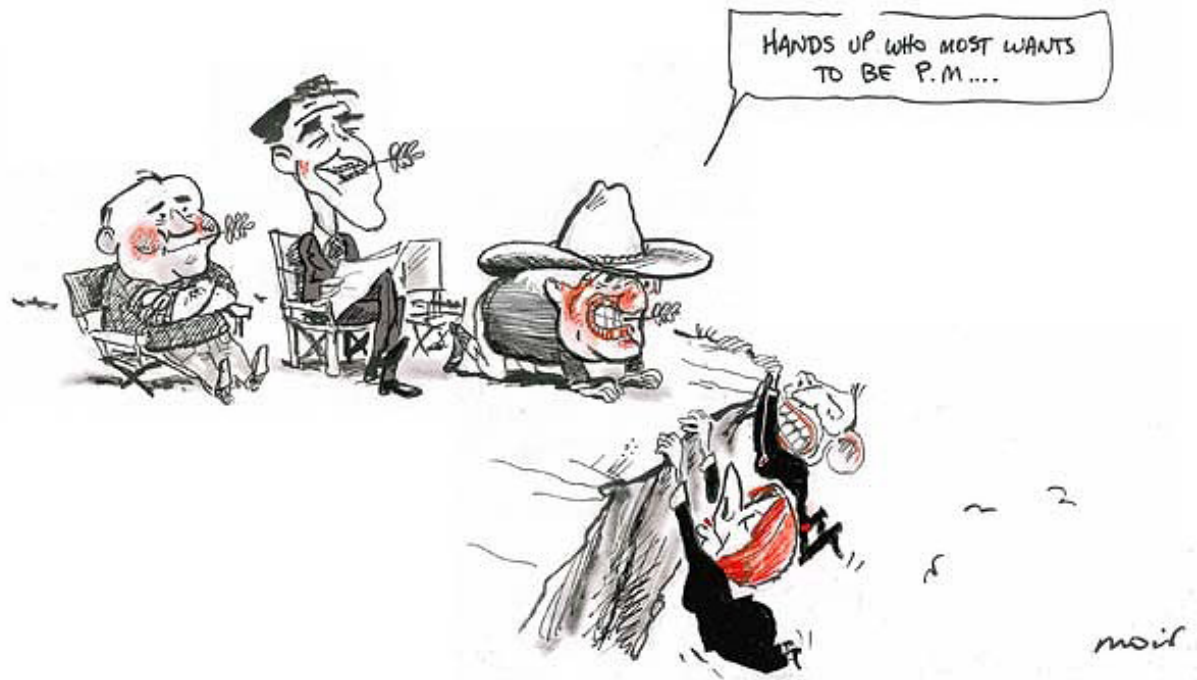

Figure 8.25 Alan Moir, Sydney Morning Herald, 27 August 2010

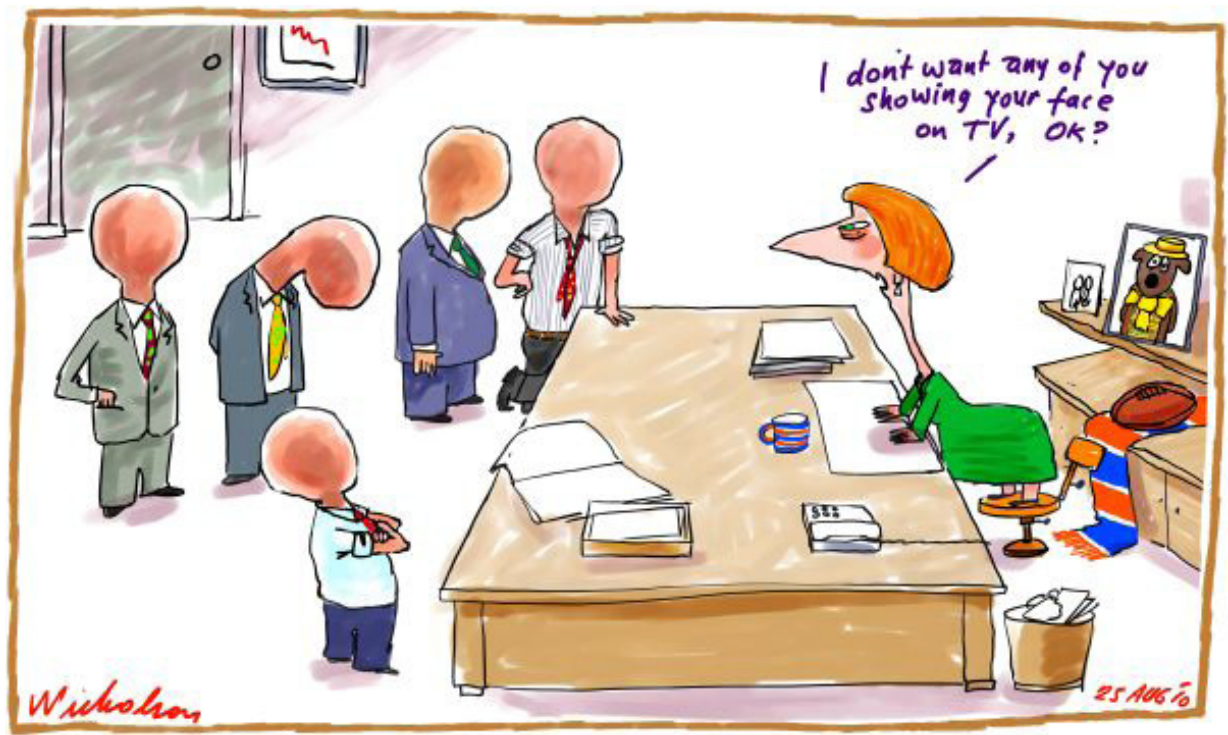

Figure 8.26 Peter Nicholson, The Australian, 25 August 2010 


\section{Summary: The opinion-poll election}

Cartoonists working to interpret and satirise the 2010 election showed how difficult it was to locate some substance to grapple with, as both sides reduced the business of winning government to simply reflecting back to electors what the campaign strategists thought they wanted to hear. Perhaps the party operatives (especially on the Labor side, but also among the Coalition) had taken the developing psephological truism that electors make up their minds later and later in campaigns too much to heart. They appear to have forgotten that, if you want to have something convincing for the last week of the campaign, you need to start building the story months and years earlier. Moir's Labor launch cartoon (Figure 8.11), with 'true believers' leaving their hearts and backbones at the door, as if they were as dangerous as guns, makes this point particularly intensely. This election-day volley by Kudelka also nails it.

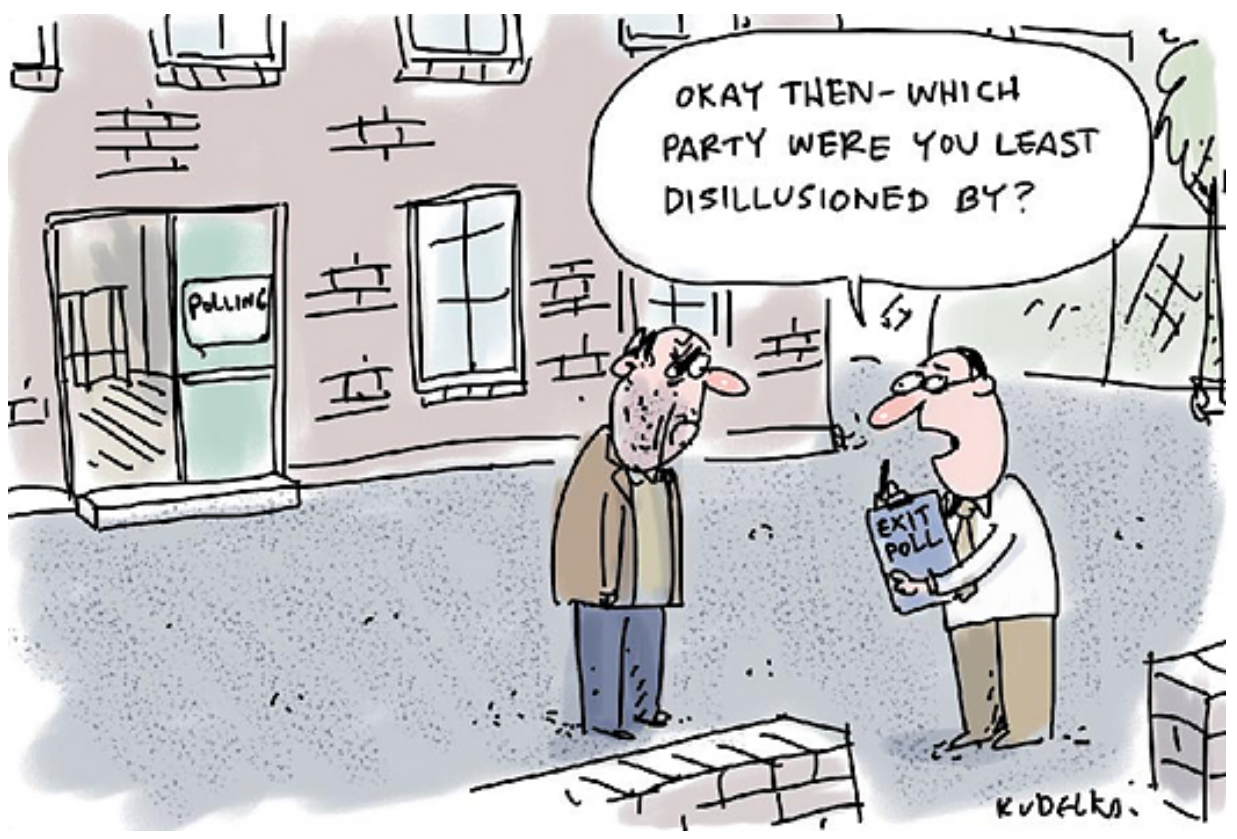

Figure 8.27 Jon Kudelka, Mercury, 21 August 2010 


\section{References}

Australian Broadcasting Corporation (ABC). 2010. Morning Program, 5 August, 891 Adelaide, ABC Radio.

Gordon, Michael. 2010. 'Prime ministerial performance from ex-PM gets to the point'. The Age, 6 August.

Manning, Haydon. 2008. 'Australian cartoonists' caricatures of women politicians-from Kirner to Stott Despoja'. In Comic Commentators: Contemporary political cartooning in Australia. Perth: API Network, 125-47.

Manning, Haydon and Phiddian, R. 2000. 'Where are the clowns? Political satire in the 1998 federal election campaign'. In Marian Simms and John Warhurst (eds), Howard's Agenda: The 1998 federal election. Brisbane: University of Queensland Press, 48-63.

Manning, Haydon and Phiddian, Robert. 2002. 'Two men and some boats - the cartoonists and the 2001 election'. In John Warhurst and Marian Simms (eds), The Centenary Election. Brisbane: University of Queensland Press, 41-62. 